Portland State University

PDXScholar

\title{
Effects of Dehydration on Hemoglobin Oxygen Affinity and Blood Cell Volume in Two Anurans
}

Andrew Christopher Zygmunt

Portland State University

Follow this and additional works at: https://pdxscholar.library.pdx.edu/open_access_etds

Part of the Biology Commons, and the Physiology Commons

Let us know how access to this document benefits you.

\section{Recommended Citation}

Zygmunt, Andrew Christopher, "Effects of Dehydration on Hemoglobin Oxygen Affinity and Blood Cell Volume in Two Anurans" (1984). Dissertations and Theses. Paper 3424.

https://doi.org/10.15760/etd.5304

This Thesis is brought to you for free and open access. It has been accepted for inclusion in Dissertations and Theses by an authorized administrator of PDXScholar. Please contact us if we can make this document more accessible: pdxscholar@pdx.edu. 
AN ABSTRACT OF THE THESIS OF Andrew Christopher Zygmunt for the Masters of Sclence in Blology presented August 3, 1984.

Title: Effects of Dehydration on Hemoglobin Oxygen Affinity and Red Blood Cell Volume in Two Anurans.

APPROVED BY MEMBERS OF THE THESIS COMMITTEE:

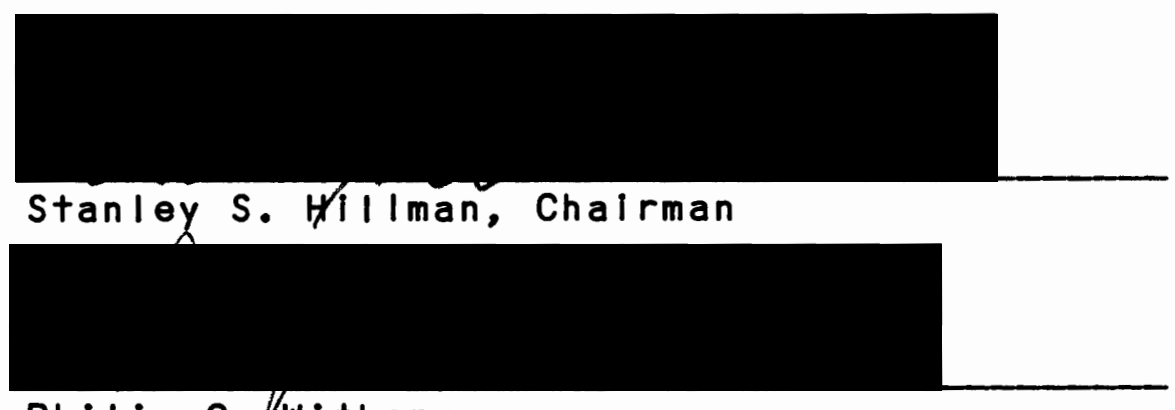

Philip C. WWithers

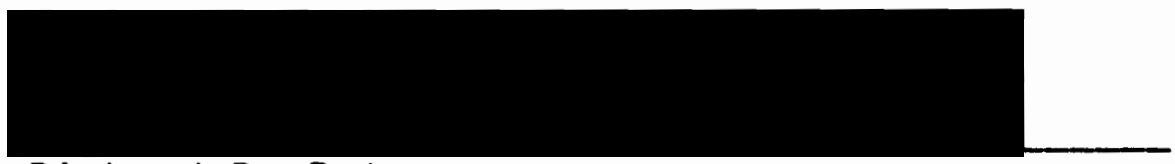

Richard R. Petersen

The degree of terrestrialism in anurans is correlated with a differential tolerance to desiccation. Cardlovascular insufficlency and reduced oxygen delivery to the tissues may be the mechanism of dehydrational death in amphiblans. 
Two aspects of possible adaptation in cardiovascular performance caused by increased plasma electrolytes were examined. Cells in anisotonic plasma may either act as osmometers or volume regulate. Blood flow rate is dependent upon cell viscosity, which in turn is a consequence of cell volume and membrane deformability. Cell volume changes which increase membrane deformability will thus potentially extend the limits of dehydration tolerance. It was found in $R$. eatesbelana and $B$. marinus that red blood cells maintain constant volume during dehydration. Celis in vitro initially lose water, but then sodium, potassium and water move into the cell. Cell viscosity within the physiologic range of hematocrits was higher in salt loaded non-regulating cells of Be marinus than in regulating isotonic cells.

A consequence of water loss in non-regulating cells, or uptake of ions in regulating cells, is an increase of intracellular ion concentration. Hyperosmolality influences oxygen loading characterlstics of blood. lonic interactions are known mediators of hemoglobin function. It was found in Bana and Bufe that increasing intracellular Ionle concentration falled to influence the oxygen dissociation curve. Adaptation was therefore not made to increase oxygen delivered to the tissues during a time of general circulatory insufficiency. 


\title{
EFFECTS OF DEHYDRATION ON HEMOGLOBIN OXYGEN AFFINITY AND BLOOD CELL VOLUME IN TWO ANURANS
}

\author{
by
}

ANDREW CHRISTOPHER ZYGMUNT
A thesis submitted in partial fulflliment of the requirements for the degree of

\section{MASTER OF SCIENCE \\ in \\ BIOLOGY}

Portland State University

1984 
TO THE OFFICE OF GRADUATE STUDIES AND RESEARCH:

The members of the committee approve the thesis of Andrew Christopher Zygmunt presented August 3, 1984.

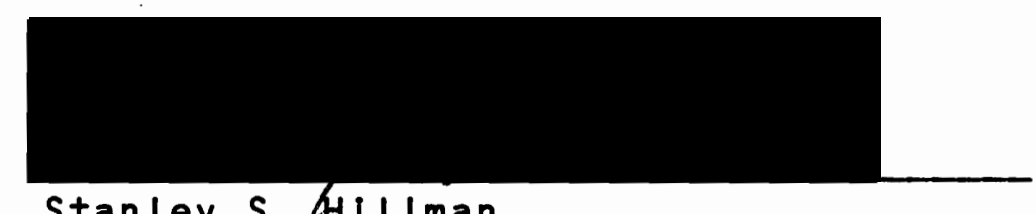
Stanley S. Hilliman

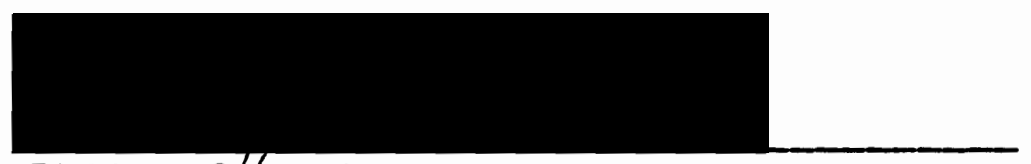

Philip CW Withers

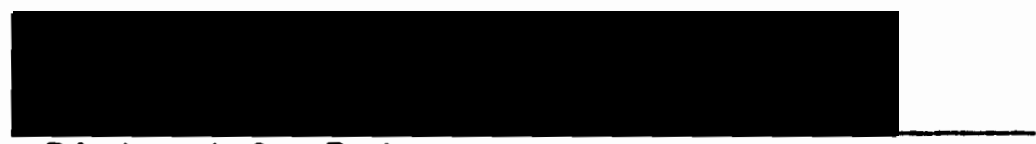

Richard S. Petersen

Walter H. Taytor, Head Department of Blology

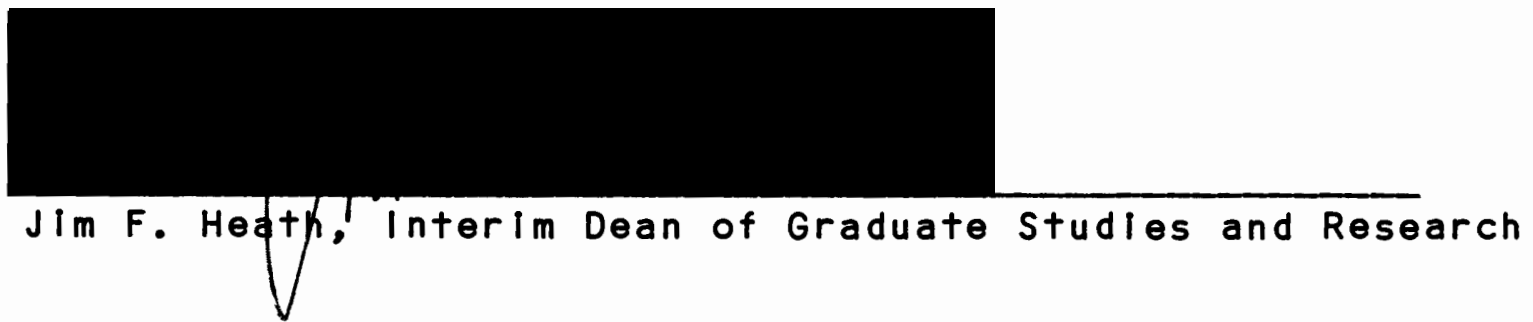




\section{ACKNOWLEDGEMENTS}

I want to thank Dr. Stan HIllman for Introduclng me to physlology and for sharing his tequila. I have valued the assistance and humor of Drs. Philip Withers, Richard Petersen, and Larry Crawshaw; as well as that of my fellow graduate students. Most importantly, without the love and caring of Diane this work would have been impossible. 


\section{TABLE OF CONTENTS}

PAGE

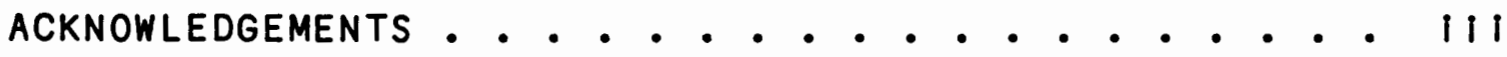

LIST OF TABLES • . . . . . . . . . . . . . . v v

LIST OF FIGURES. . . . . . . . . . . . . . . . vi

INTRODUCT ION •. . . . . . . . . . . . . . . . . 1

MATERIALS AND METHODS. . . . . . . . . . . . . 8

Animals . . . . . . . . . . . . . . 8

Mean Cell Volume. . . . . . . . . . . 8

Hemoglobin oxygen Affinity. . . . . . . . . 11

Intracellular Sodium and Potassium. . . . . . . 12

viscosity . . . . . . . . . . . . . . 13

RESULTS. . . . . . . . . . . . . . . 13

Mean Cell Volume. . . . . . . . . . . 13

Hemoglobin Oxygen Affinity. . . . . . . . . 15

Intracellular Sodium and Potassium. . . . . . 15

viscosity. . . . . . . . . . . . 15

DISCUSSION . . . . . . . . . . . . . . . . . 26

REFERENCES . . . . . . . . . . . . . . . . 32 


\section{LIST OF TABLES}

TABLE

PAGE

I Intracellular sodium and potassium

concentrations ( $m E q / K g$ dry mass) in the

erythrocytes of Be marinus $(n=9)$ and $B$ e catesbelana $(n=9)$. Values are means \pm standard error assuming $10 \%$ trapped plasma. Asterisk indicates significant difference $(p<0.025) \ldots \ldots \ldots \ldots \ldots \ldots \ldots \ldots . \ldots \ldots$ 
1. In vivo volume of erythrocytes of B. marinus (water losses 28-36\% initial body mass)

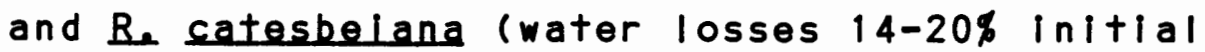
body mass) . . . . . . . . . . . 18

2. Temperature dependence of RBC volume regulation in $B_{\text {. }}$ marinus and $R_{\text {. }}$ catesbelana. Rana.

( $\triangle 90 \mathrm{C}$ isotonic, $200 \mathrm{C}$ isotonic, $90 \mathrm{~g}$ hypertonic, $200 c$ hypertonic). Bufe, ( 900 isotonic,

- $200 \mathrm{C}$ isotonic, $\nabla 90 \mathrm{C}$ hypertonic $200 \mathrm{C}$ hypertonic) . . . . . . . . . . . . . . . 19

3. Volume regulation of RBC's in Re catesbelana after 1.5 hours. Top line indicates behavior as osmometer, $y=71.5( \pm 0.4) x-0.1( \pm 0.1), r=1.00$. Bottom line RBC's in normal Ringer's, $y=21.0( \pm 5.3) x-0.4( \pm 2.0), r=.78$. ( $\Delta$, potassium free media; $\nabla$, oubain media; D normal Ringer's). . . . . . . 20 
4. Volume regulation of RBC's in Be marlnus after 1.5 hours. Top line is behavior asosmometer, $y=66.7( \pm 0.5) x+0.1( \pm 0.1), r=1.00$. Bottom line RBC's in normal Ringer's, $y=26.9( \pm 2.8) x-0.3( \pm 1.1)$ $r=.94$. ( $\Delta$, potassium free media; $\nabla$, oubain media; , normal Ringer's)......... 21

5. The relationship between red cell intracellular ion concentrations and plasma electrolytes in R. catesbelana corrected for $10 \%$ trapped plasma. (O) sodium $y=0.5 x-21, r=.75 ; \Delta$ potassium $y=1.1 x+97$, $r=.93$. ) . . . . . . . . . . . . . 22

6. The relationship between red cell intracellular ion concentrations and plasma electrolytes in Bemarinus corrected for $10 \%$ trapped plasma.

(O sodium $y=0.5 x-14, r=.73 ; \Delta$ potassium $y=0.4 x+190$, $r=.79$ ). . . . . . . . . . . . 23

7. The relationship between B. marinus hematocrit and the In transformation of red cell viscosity at a shear rate of $450 / \mathrm{sec}$ and $200 \mathrm{c}$. Solld line is salt loaded $(180 \mathrm{mEq} / \mathrm{L})$, In $y=0.028( \pm .001) x+0.90$ $( \pm .04), r=.98$. Dashed line is isotonic plasma, $\ln y=0.035( \pm .002) x+0.43( \pm .07), r=.93 . . . .24$ 


\section{INTRODUCTION}

Anurans are a diverse group of some 3000 species which occupy habitats ranging from rain forests to deserts. Although the vast majorlty of species are freshwater, their number includes species adapted for marine environments. Modern anurans are descendants of the first vertebrates to face the desiccating environment of a terrestrial habitat. The examination of the physlological correlates associated with their degree of terrestrialism has been a fruitful inquiry.

Water balance in anurans has been described by a number of workers. With a few exceptions, (Phyllomedusa, Chiromantis, and Hyperollus), frogs and toads have cutaneous evaporative water loss rates equal to a free water surface (Bentley 1966a). Thorson (1955) found no correlation between evaporative water loss and degree of terrestrialism, but did find a high correlation between increased tolerance to water loss and xerlc habitats. Hillman (1980) found the aquatic species Xenopus Laevis to tolerate $34 \%$ loss of initial body mass, whereas scaphlopus couchll, an animal found in desert areas with access only to temporary ponds and soll molsture, tolerated a loss of 45\% before dehydrational death. 
The physiological basis for interspecific dehydration tolerance has recently begun to emerge. A terrestrial vertebrate in negative water balance is necessarlly dependent upon stored water. A positive correlation exists between increased capacity of anuran urinary bladders and terrestrialism. Bladder capacity ranges between 1\% body

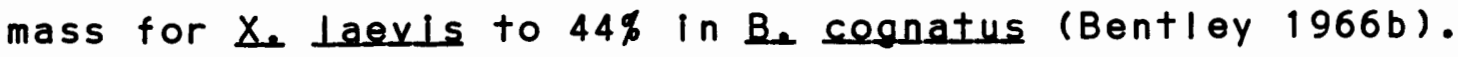
Rulbal (1962), Shoemaker (1964), and McClanahan (1967) have shown that bufonids and pelobatids maintain normal body fluld concentrations until bladder stores are depleted. Since anurans lack salt glands and kidneys stop urine formation during dehydration, the osmotic concentration of body fluids must increase after depletion of bladder water. Shoemaker (1964) has formulated the following equation to describe the increase in plasma electrolytes with dehydration:

$$
C f=C_{O} *(B W O /(B W O-W D)
$$

where

$$
\begin{aligned}
& C f=f i n a l \text { plasma osmolarity } \\
& \text { Co=original plasma osmolarity. } \\
& B W O=\text { original body water content } \\
& W D=\text { water deficit }
\end{aligned}
$$

Further bases for graded dehydration tolerance were found by Hillman (1976, 1978). Terrestrial species 
B. coanatus and $S$ e couchll have increased oxygen storage capabilities and maximum oxygen consumptions ( $\mathrm{V}_{2}$ max). He found positive correlations between ventricle mass and $\dot{V} o_{2} \max , a$ significant decrease in $\dot{V} o_{2} \max w i t h$ dehydration, and an increase in whole animal lactate at critical activity point (loss of righting response). The implication is that terrestrialism is associated with selection for Increased aerobic capacity and that dehydrational death in the species investigated is brought on by a reduction in circulatory oxygen delivery.

Possible mechanisms for reduction in $\mathrm{O}_{2}$ delivered to the tissues include the effects of hyperosmolality, hypovolemia, and viscosity. Investigations of the contractile performance of cardlac muscle bathed in hyperosmotic solutions have shown both postive (Koch-Weser 1963; Atkins et al. 1973), and negative inotroplc effects, (WIIdenthal 1975; HIIIman 1984). HIIIman (1978, 1980) demonstrated Increased tolerance for plasma sodium in terrestrial species and suggested that a necessary adaptation for extending deydration tolerance is to extend the intrinsic osmotic IImit. This effect of electrolytes was found to be independent of hematocrit and thus viscosity effects.

Compensation assoclated with hypovolemic stress was shown by Hillman and Sommerfeldt (1981) to Include a redistribution of blood flow to the head, enhanced return 
of lymph to the plasma space, (HIIlman and Zygmunt, unpublished), and an increase of resting heart rate (Hillman 1978). In this manner brain function and cardiac output is maintained.

Blood flow rate is inversely proportional to blood viscosity. During dehydration, blood viscosity increases after bladder and lymph fluld volumes have been exhausted. Any compensation in circulatory resistance involving dilation of peripheral vessels is counter-productive since the appropriate response to hypovolemia is constriction of the peripheral vessels.

To summarlze, dehydrational death in anurans appears to be the result of curtallment of oxygen delivery to the tissues, resulting from hypovolemia, hyperviscosity, and hyperosmolality. Consequently, adaptations which faclilitate oxygen delivery with dehydration should enhance tolerance. The objectives of this study were to investigate aspects of the effects of increased plasma electrolytes during dehydration on RBC function in Re catesbelana and B. marinus.

Two aspects of red cell function under hyperosmotic stress are germane to the question of oxygen dellivery. The first is whether the red blood cells volume regulate or not with hyperosmolality. Cell deformablilty is a functional consequence of cell volume. Blood viscosity is related to cell deformability, hence cell volume. Mechanisms which 
reduce blood viscosity with dehydration will enhance oxygen delivery and be adaptive relative to dehydrational tolerance. The second question is whether the hyperosmolality influences the oxygen loading characteristics of the blood. Ionic interactions are known to mediate hemoglobin oxygen loading. During dehydration intracellular ionic strength increases, therefore the effects of hyperosmolality on oxygen dissociation curves is central to understanding hyperosmotic stress on oxygen del ivery.

One aspect of the inability to regulate plasma electrolytes is that cells will be bathed in hyperosmotic fluids. Net movement of water is dependent upon extracellular osmolality. In hypertonic solutions, cell volumes will decrease unless intracellular osmolyte concentrations are increased to match extracellular osmolality. A number of investigators have examined volume regulation of cells in anisotonic media. Shoemaker (1964) found retention of water in skeletal muscle, liver, kidney, lung, and heart in the toad Be marinus after dehydration to $80 \%$ of original mass. He assoclated this volume regulation with an increase in cellular electrolytes, $\left(\mathrm{Na}^{+}, \mathrm{K}^{+}, \mathrm{Cl}^{-}\right)$. Katz (1978) found differential volume regulation in tissues of Be viridis. A reduction in water content between 15-30\% was found for erythrocytes, muscle, and liver. Heart water content changed very little after adaptation to $500 \mathrm{~m} 0 \mathrm{sm}$ 
$\mathrm{NaCl}$. Oubain $\left(10^{-3} \mathrm{M}\right)$, an active transport blocker, affected ionic composition, but not cellular water content. Studies of erythrocytes in hypotonlc media have shown volume regulation to be the result of either reduction in cell free amino acids (Fugelli 1967; Costa and Pierce 1983), or cell electrolytes (Kregenow 1971a). Duck red cells in hypertonic media increase cellular $\mathrm{Na}^{+}$and $\mathrm{K}^{+}$ content after an initial period of cell shrinking (Kregenow $1971 \mathrm{~b})$.

Red cells in anisotonic solutions change surface to volume ratio and packing of cell hemoglobin. These factors potentially affect blood viscosity. Investigators have reported conflicting results. Melselman et al. (1967) found hypertonic suspensions of red cells to have increased viscosity, whereas cells in hypotonic solution had reduced viscosity relative to controls. Rand and Burton (1964) found red cell membranes to be more easily deformed in hypertonic solutions. Increased deformability should yield a reduced viscosity (Braasch 1971). I have investigated blood viscosity over a range of hematocrits in salt loaded red blood cells. These experiments answer questions regarding possible viscosity advantages in regulating vs nonregulating nucleated red cells. A reduction in viscosity offers an obvious advantage in oxygen delivery.

If erythrocytes maintain volume as a consequence of intracellular uptake of electrolytes, or if they simply 
lose water, it would be expected that the oxygen dissoclation curve would be shifted to the right, due to an increase in intracellular ion concentration (Rossi-Fanelli et al. 1961; Brunorl et al. 1975). A rightward shlft of the curve would be a useful adaptation for promoting the oxygen supply to the tissues by decreasing hemoglobin affinity for oxygen (Lenfant et al. 1970; Metcalfe and Dhindsa 1970). Faclilitation of $\mathrm{O}_{2}$ delivery at the tissues would offset general circulatory insufficiency which accompanies dehydration. I have undertaken experiments to determine the half saturation point of hemoglobin in control and dehydrated animals. The half saturation point of hemoglobin, $\left(P_{50}\right)$, is a measure of the position of the oxygen dissociation curve.

In summary, the thrust of this study is to elucldate factors for possible compensation of problems involved with $0_{2}$ delivery during dehydration in anurans.

These factors arlse from reduced cell volume in hypertonic media, or from increased intracellular ionic concentration with dehydration. A comparison between species of differing tolerance to dehydration, (Bufo>Bana), may identify adaptations for terrestrial radiation in anurans. 


\section{Materlals and Methods}

Animals

Bute marlnus (mean mass $=253 \mathrm{~g}$ ) and Rana catesbelana (mean mass $=438 \mathrm{~g}$ ) were purchased from commerclal suppliers. B. marlnus were maintained in the lab between 17-200C on a sand substrate. Pans of distilled water were included within the enclosure for rehydration.

R. catesbelana were kept in a sheet metal enclosure with avallable water and were used within two weeks of arrival in the lab.

Mean Cell Volume

Mean cell volume (mcv) determinations were made using a Coulter Counter, (model Zbl), and Channel|zer, (model (-1000), interfaced with a Tektronix 4051 computer. The counter produces a pulse which is in principle proportional to the volume of suspension electrolyte displaced by a cell within the counting aperture. The current pulse is theoretically assumed to be caused by an insulating particle moving within a conducting medium, and this predicts that mcr measurements wlll be affected by cell membrane charge. Adams and Gregg (1972) found that errors introduced by cell charges are insignificant due to the 
comparatively large reslstive current of the electrolyte. Additional errors due to cell path, tumbling of the cell, and adherent cells passing through the aperture as doublets, were reduced by use of an electronic editor on the model C-1000 Channelizer. Coulter Electronics suggest cell counts be less than $40,000 \mathrm{cell} / \mathrm{s} / \mathrm{ml}$ for the $100 \mathrm{micron}$ aperture tube to reduce counting errors, a procedure always followed in these experiments. Further correction for the above anomalies was made by using human red blood cells in Isotonic solution to calibrate the counter and channelizer. Since experiments required cells to be suspended in electrolyte of increasing tonicity, mev determinations for a 23.2 micron diameter latex bead (Coulter Electronics) were made in salt solutions covering the range experlenced by dehydrated individuals. For sodium concentrations between 100-250 mM, mcv as determined on the Coulter counter was within $1 \%$ of its calculated volume assuming the latex particle to be a sphere.

Volume regulation experiments fell into two catagories. Red blood cell ( $r b c$ ) volume was followed during dehydration in $B$. marinus $(n=6)$ and $B_{\text {e catesbelana }}$ $(n=6)$. Animals were weighed after their bladder was drained by cloacal cannulation. After control blood samples were obtalned by ventricular puncture, animals were placed in screened plastic cages and subsequently lost 6-9\% of initial body mass/day. Dally blood sampling continued 
until water losses of $35 \%$ initial body mass in Bufo and $24 \%$ In Rana were achieved. Control and all subsequent blood sampling was made by ventricle puncture. Blood was collected in heparinized tubes and a quantity of whole blood was centrifuged at 4,000 rpm for $2 \mathrm{~min}$. Hematocrit was recorded and plasma sodium and potassium determined on an IL model $143 \mathrm{flame}$ photometer. Red cells whlch were to be analysed by the Coulter counter were suspended in Ringer's isotonic for the nonpermeant sodium lon, and containing $5 \mathrm{mM} \mathrm{KHCO}_{3}, 1 \mathrm{mM} \mathrm{CaCl}, 5 \mathrm{mM} \mathrm{glucose}$.

Additional experiments were performed to describe the effects of temperature, extracellular potasslum, and the function of the $\mathrm{Na}^{+} / \mathrm{K}^{+}$pump on cell volume regulation. Blood obtalned by heart puncture from hydrated B. marinus

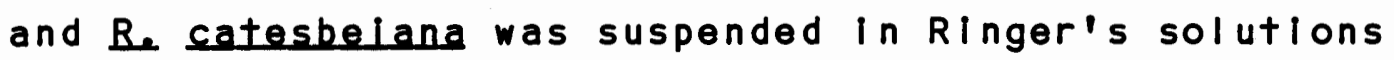
ranging from isotonic to solutions containing $225 \mathrm{mM} \mathrm{Na}^{+}$. These suspensions were malntalned at either $20^{\circ} \mathrm{C}$ or $9^{\circ} \mathrm{C}$ and mev determinations made every 15 minutes for 2 hours. A comparison of the degree and time course of volume regulation was made between cells maintalned at the two temperatures.

In order to investigate possible ionic contributions to volume regulation, red cells from hydrated B. marinus and $R$. catesbelana were placed in hypertonic media which were elther potasslum free or contalned oubaln at a concentration of $10^{-3} \mathrm{M}$. At this concentration, oubain 
blocks the operation of the $\mathrm{Na}^{+} / \mathrm{K}^{+}$pump (Kregenow 1971b). Mean cell volume comparisons were made between cells in hypertonic normal, $\mathrm{K}^{+}$free, and oubain medla.

Hemoglobin Oxygen Affinity

Hydrated B. marinus $(n=12)$ and $B_{\text {e catesbelana }}$

$(n=12)$ were doubly pithed, after which the ventricle was exposed. A $4 \mathrm{ml}$ sample of blood was collected in a syringe containing heparin. Blood from dehydrated Bufe $(35 \%$ loss initial body mass, $n=9$ ) and Rana (20\% loss initial body mass, $n=6$ ) was similarliy collected.

Measurement of the half saturation point of hemoglobin $\left(P_{50}\right)$ was made using the technique of Edwards and Martin, (1966). Four $m l$ of blood was divided between 2 test tubes and each tube sealed by rubber stopper. Two 18 gauge needles on which 3-way stopcocks had been mounted allowed fllling of each test tube with gas mixtures under a positive pressure. Within these equllibration tubes, whole blood was fully oxygenated (gas mixture $20 \% \mathrm{O}_{2}, 5 \% \mathrm{CO}_{2}$, balance $\mathrm{N}_{2}$ ) or fully deoxygenated (gas mixture $5 \% \mathrm{CO}_{2}$, balance $\mathrm{N}_{2}$ ). After an equilibration of $45 \mathrm{~min}, 150 \mathrm{ul}$ oxygenated blood was injected in a 300 ul caplllary tube, followed by immediate injection of 150 ul deoxygenated blood into the column of saturated blood. This volume of blood was mixed anaerobically and analyzed for $\mathrm{Po}_{2}, \mathrm{PH}$, and $\mathrm{Pco}_{2}$ at $19^{\circ} \mathrm{C}$ using an IL model 313 blood gas analyzer. 
Since equilibrium oxyhemoglobin saturation is dependent upon the relative volume contribution of saturated Hb to the total volume of mixed blood, the $\mathrm{PO}_{2}$ of a mixture of equal volumes of oxygenated and deoxygenated blood is the $\mathrm{P}_{50}$. Determinations were made at a temperature of $19^{\circ} \mathrm{C}, \mathrm{pH}$ 7.55, and $\mathrm{PCO}_{2}$ of $40 \mathrm{mmHg}$.

Intracellular Sodium and Potassium

Approximately $2 \mathrm{ml}$ of blood was collected by heart puncture from fully hydrated B. marlnus $(n=9)$ and R. catesbelana $(n=7)$. Individuals were subsequently dehydrated until they lost $35 \%$ of initial body mass in Bufo and 25\% in Bana. Animals were doubly pithed and the ventricle exposed for blood collection in heparinized syringes.

Blood was centrifuged at $4,000 \mathrm{rpm}$ for $10 \mathrm{~min}$ in 300 ul capillary tubes. Plasma and white cell fraction were removed and the red cells were blown into test tubes welghed to the nearest $0.1 \mathrm{mg}$, (Sauter model 414 balance). Red cells were dried to constant mass at $40^{\circ} \mathrm{C}$. Two $\mathrm{ml}$ of $0.8 \mathrm{~N} \mathrm{HNO}_{3}$ was used to extract $\mathrm{Na}^{+}$and $\mathrm{K}^{+}$from the cells. Aliquots of $100 \mathrm{ul}, 500 \mathrm{ul}$, and $1 \mathrm{ml}$ were evaporated to dryness in order to concentrate ions. Lithium diluent was added and determinations made on an IL model 143 flame photometer. After correction for trapped plasma, (10\% wet 
mass), intracellular concentrations were expressed as meQ/Kg dry mass cells.

Viscosity

Bufe marlnus $(n=3)$ were doubly pithed and the ventricle exposed. Blood was collected in test tubes containing ammonium heparin and centrifuged at 4,000 rpm for $5 \mathrm{~min}$. Separated plasma was salt loaded to a concentration of 180 meQ $\mathrm{NaCl}$. Red cells were then suspended in salt loaded plasma in order to manufacture hematocrits between 0-77\%. A 200 ul sample of suspended cells was immediately analysed at $200 \mathrm{C}$ with a Wells-Brookfield cone/plate viscometer model LVTDCP. Viscosity reported was for a shear rate of $450 /$ sec. RBC's in hypertonic media initially behave as osmometers before gaining water (Figure 2). Cells placed in salt loaded plasma for immediate viscosity determinations are thus termed nonregulating. Comparison was made with viscosity of red cells in isotonic plasma of hydrated Bufo (Hedrick, unpublished).

\section{RESULTS}

Mean Cell Volume

The results of in vivo regulation of red cell volume in Be catesbelana and B. marinus are shown in Figure 1. Mean cell volume of hydrated $R_{\text {e catesbelana }}(n=4)$ was $770 \pm$ 
$20 u^{3}$ ( $\left.\pm s e\right)$. Loss of 14-20\% of initial body mass resulted in a mev of $771 \pm 18 \mathrm{u}^{3}$. Mean cell volume of Be marinus $(n=4)$ red cells was $460 \pm 11 \mathrm{u}^{3}$, and $451 \pm 11 \mathrm{u}^{3}$ after water losses ranging from 28-36\% of initial body mass. These data indicate volume regulation since predicted reduction of initial volumes should equal $15 \%$ in $B$. catesbelana and $28 \%$ in B. marinus if these cells acted as perfect osmometers in hypertonic plasma.

The mechanism of volume regulation is temperature dependent as shown in figure 2 for both species. Recovery of cell volume after challenge by hypertonic medium, ( 180 mEq $\mathrm{Na}^{+}$), occurs within 45 minutes at $200 \mathrm{C}$, whereas at $90 \mathrm{C}$, recovery is incomplete after 2.5 hours.

The results of in vitro experiments involving regulation in potassium free solutions and normal Ringer's containing oubain $\left(10^{-3} \mathrm{M}\right)$ is shown for R. catesbelana (Figure 3 ) and $B$. marinus (Figure 4 ). The relationships between percent decrease of initial cell volume and media tonicity were similar in both species. Cells placed in $\mathrm{K}^{+}$ free media behaved as simple osmometers and did not volume regulate $(p>0.05)$. In a similar fashion, slopes of regression lines for cells in normal and oubain Ringer's were not different $(p>0.05)$. A significant decrease in slopes was found between predicted osmometer and cells in normal Ringer's $(p<0.01)$, or cells in Ringer's plus oubain. 
Evidently, extracellular potassium is required for the observed volume regulation, but oubain has no effect.

Hemoglobin Oxygen Affinity

No difference $(p>0.05)$ was found between hydrated and dehydrated hemoglobin oxygen affinities in either species. $P_{50}$ was determined to be $48.8 \pm 1.4$ torr $(n=12)$ and 50.6 \pm 1.6 torr $(n=6)$, respectively, in hydrated and dehydrated B. catesbelana. Oxygen affinity was greater in Be marinus; $41.6 \pm 1.4$ torr $(n=12)$ in hydrated animals and $43.0 \pm 0.5$ torr $(n=9)$ in dehydrated individuals.

Intracellular Sodium and Potassium

The relationships between plasma sodium and intracellular ion concentration were similar for both species (Figures 5 and 6 ). A significant increase of intracellular $\mathrm{K}^{+}$and $\mathrm{Na}^{+}$concentrations accompanied dehydration in both species $(p<0.05)$. Results are listed In Table 1 .

viscosity

Figure 7 shows the viscosity relationships for B. marinus red cells in isotonic and hypertonic $(180 \mathrm{mEq}$ $\mathrm{Na}^{+}$) solutions. The slope is significantly lower $(p<0.005)$ and the intercept higher $(p<0.001)$ in salt stressed cells. A higher intercept may be the result of salt interactions 
with plasma proteins. Control plasma viscosity $(1.8 \pm$

$0.04 \mathrm{cP}$ ) was lower than viscosity of plasma loaded to 180 $\mathrm{mEq} \mathrm{Na}{ }^{+}(2.6 \pm 0.07 \mathrm{cP})$. 
TABLE $\quad$

INTRACELLULAR SODIUM AND POTASSIUM CONCENTRATIONS (MEQ/KG DRY MASS) IN THE ERYTHROCYTES OF B. MARINUS $(N=9)$ AND R. CATESBELANA $(N=9)$. VALUES ARE MEANS \pm STANDARD ERROR ASSUMING $10 \%$ TRAPPED PLASMA. ASTERISK INDICATES SIGNIFICANT DIFFERENCE $(P<0.025)$.

SPECIES

CONTROL DEHYDRATED

B. marinus

$$
\begin{array}{rrr}
\mathrm{Na}^{+} & 40.4 \pm 1.7 & 73.2 \pm 8.7^{*} \\
\mathrm{~K}^{+} & 234.8 \pm 2.3 & 260.6 \pm 6.0^{*}
\end{array}
$$

B. catesbelana

$$
\begin{aligned}
& \mathrm{Na}^{+} 34.1 \pm 2.3 \\
& \mathrm{~K}^{+} 229.0 \pm 3.4
\end{aligned}
$$$$
58.3 \pm 3.7^{*}
$$$$
269.0 \pm 8.8^{*}
$$ 


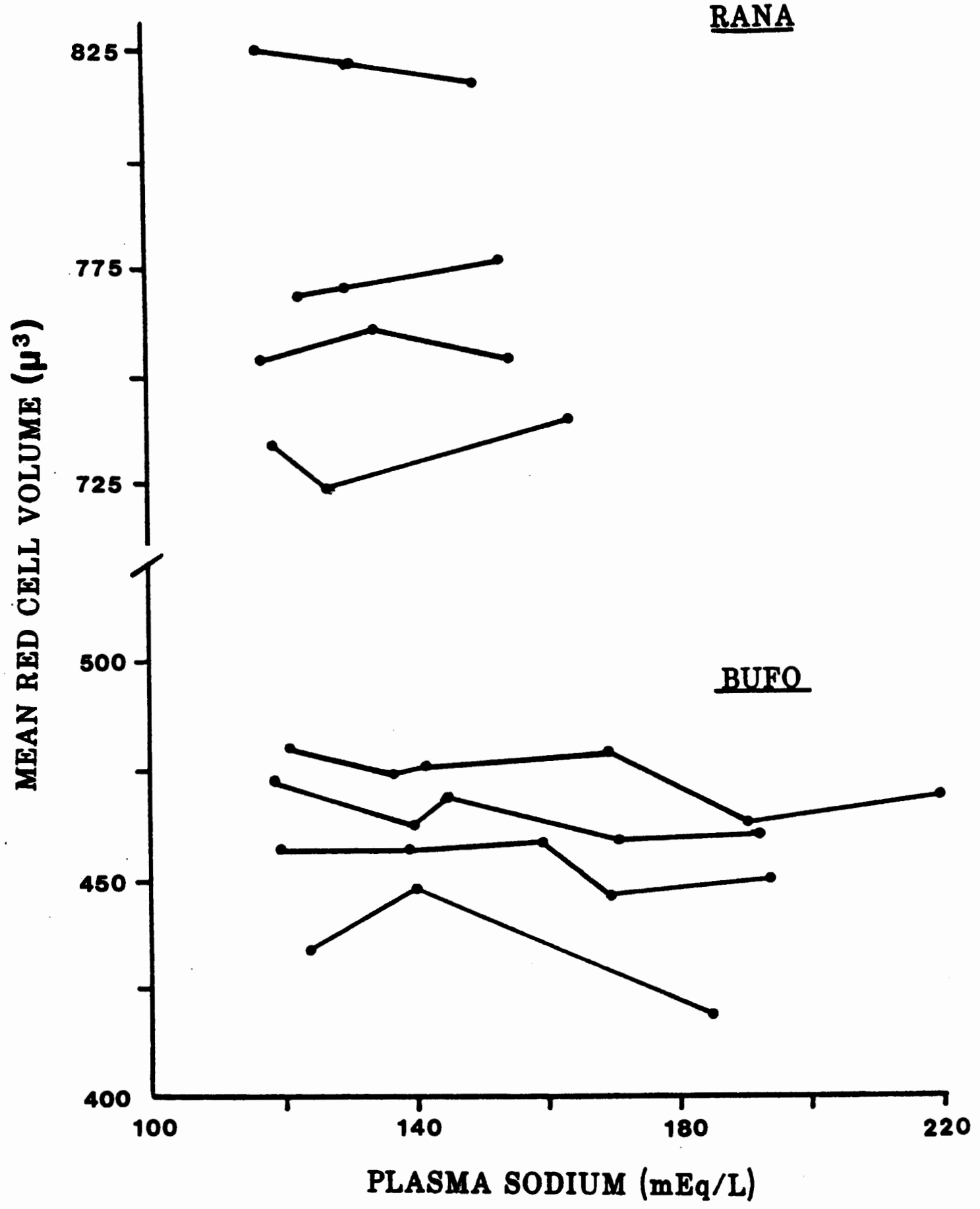

Figure 1. In vivo volume of erythrocytes of $B$. marinus (water losses 28-36\% initial body mass)

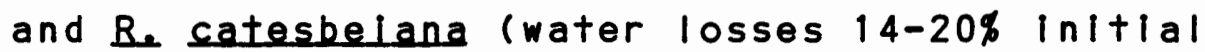
body mass). 


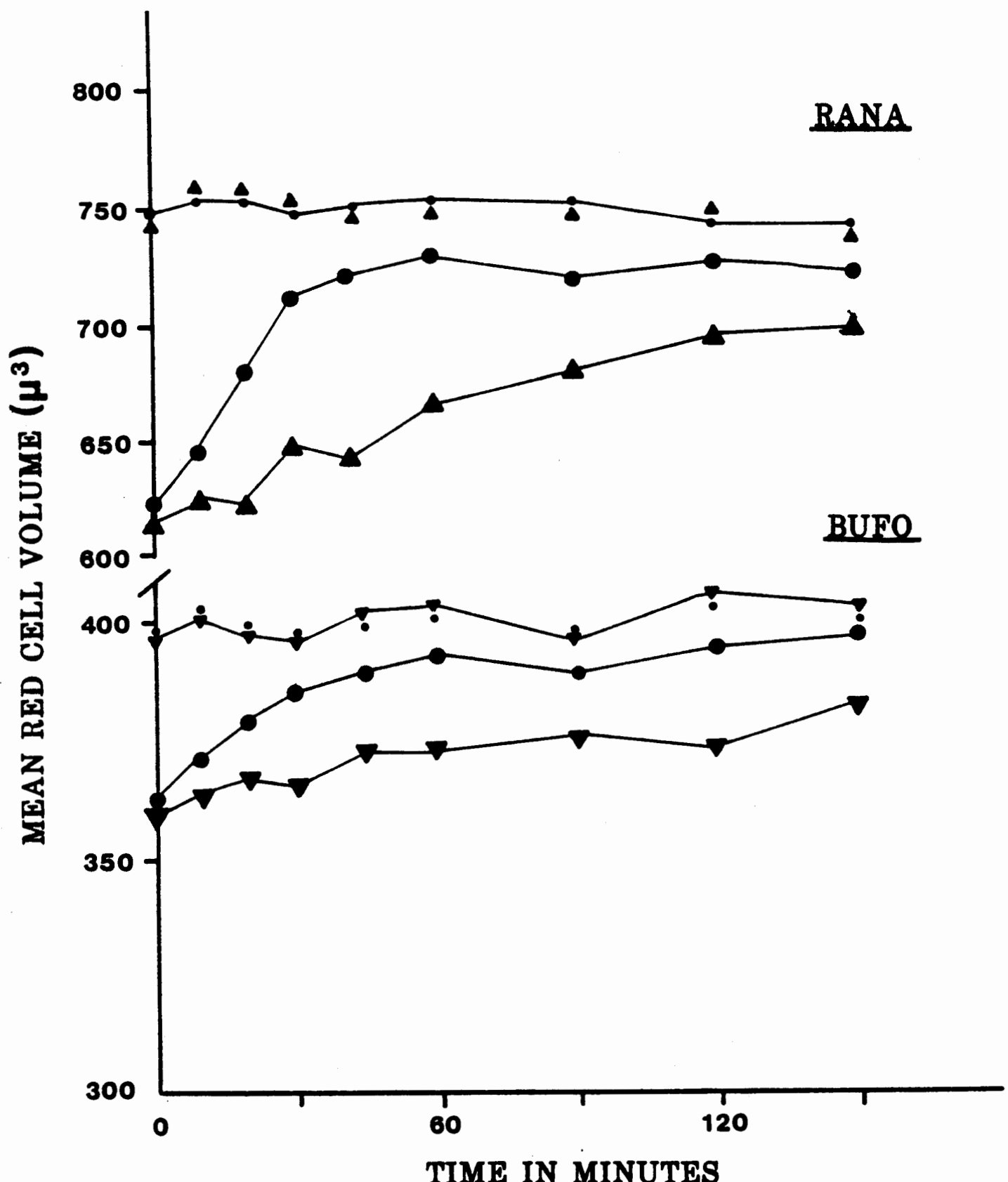

Figure 2. Temperature dependence of RBC volume regulation in $B_{\text {. }}$ marlnus and $B_{\text {e catesbelana. Rana. }}$ $\left(\triangle 9^{\circ} \mathrm{C}\right.$ isotonic, $20^{\circ} \mathrm{C}$ isotonic, $\Delta 9^{\circ} \mathrm{C}$ hypertonic, $20^{\circ} \mathrm{C}$ hypertonic). Bufo, $\left(\nabla 9^{\circ} \mathrm{C}\right.$ isotonic, - $20^{\circ} \mathrm{C}$ isotonic $\sqrt{ } 9^{\circ} \mathrm{C}$ hypertonic $20^{\circ} \mathrm{C}$ hypertonic). 


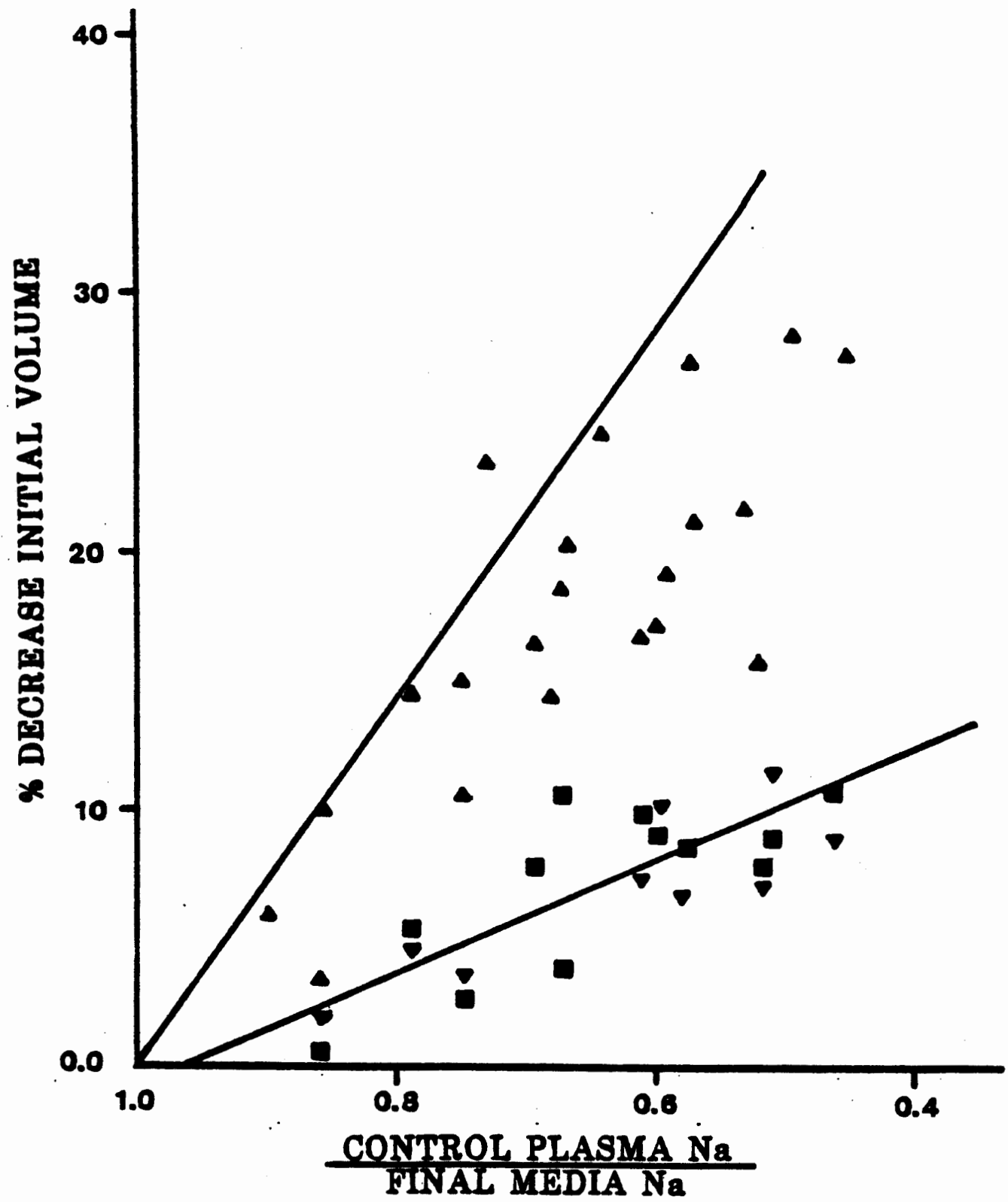

Figure 3. Volume regulation of RBC's in $R$. catesbelana after 1.5 hours. Top I ine indicates behavior as osmometer, $y=71.5( \pm 0.4) x-0.1( \pm 0.1)$, $r=1.00$. Bottom I ine RBC's in normal Ringer's, $y=21.0( \pm 5.3) x-0.4( \pm 2.0), r=.78$ $(\Delta$, potassium free media; $\nabla$, oubain media; - normal R(nger's) 


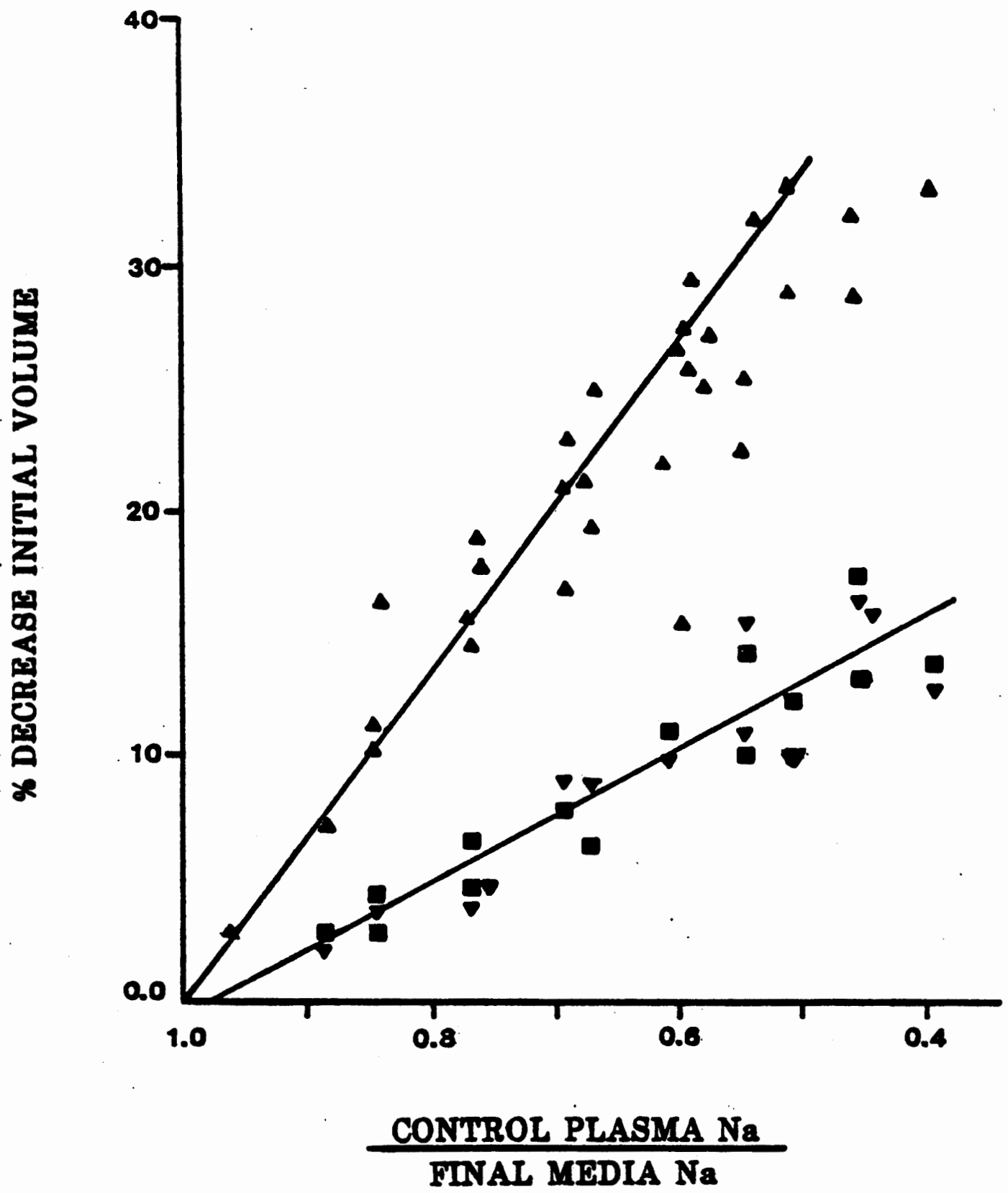

Figure 4. Volume regulation of RBC's in Be marinus after 1.5 hours. Top line is behavior as osmometer, $y=66.7( \pm 0.5) x+0.1( \pm 0.1), r=1.00$. Bottom I ine RBC's in normal Ringer's, $y=26.9( \pm 2.8) x-0.3( \pm 1.1)$, $r=.94$. ( $\Delta$, potassium free media; $\boldsymbol{\nabla}$, oubain media; $\square$, normal Ringer's) 


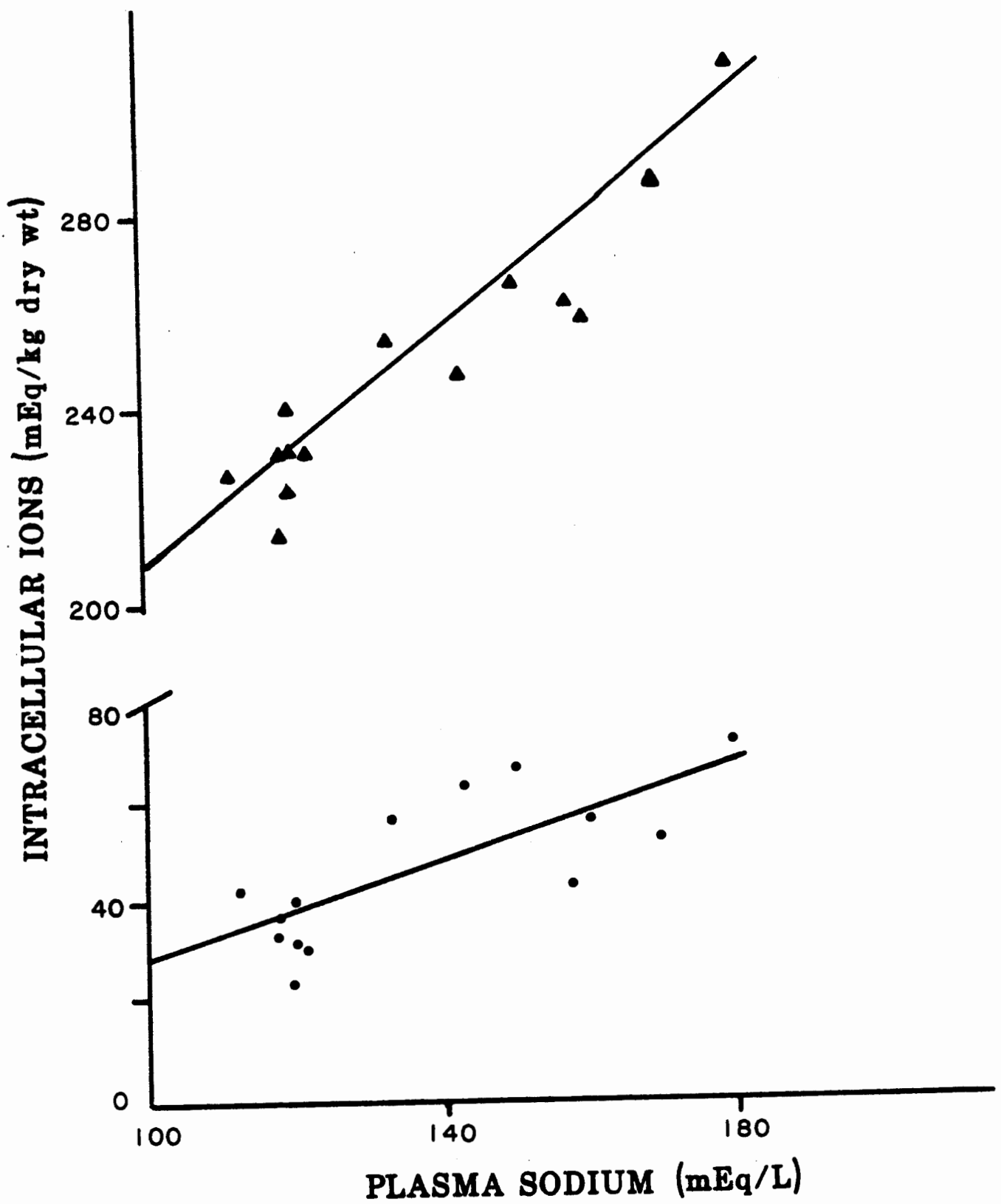

Figure 5. The relationship between red cell intracellular ion concentrations and plasma

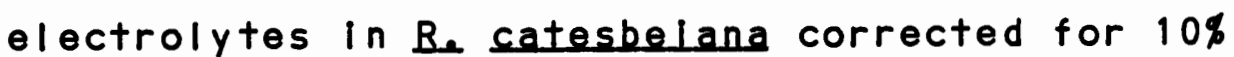
trapped plasma.

(O sodium $y=0.5 x-21, r=.75 ; \Delta$ potassium $y=1.1 x+97$, $r=.93)$. 


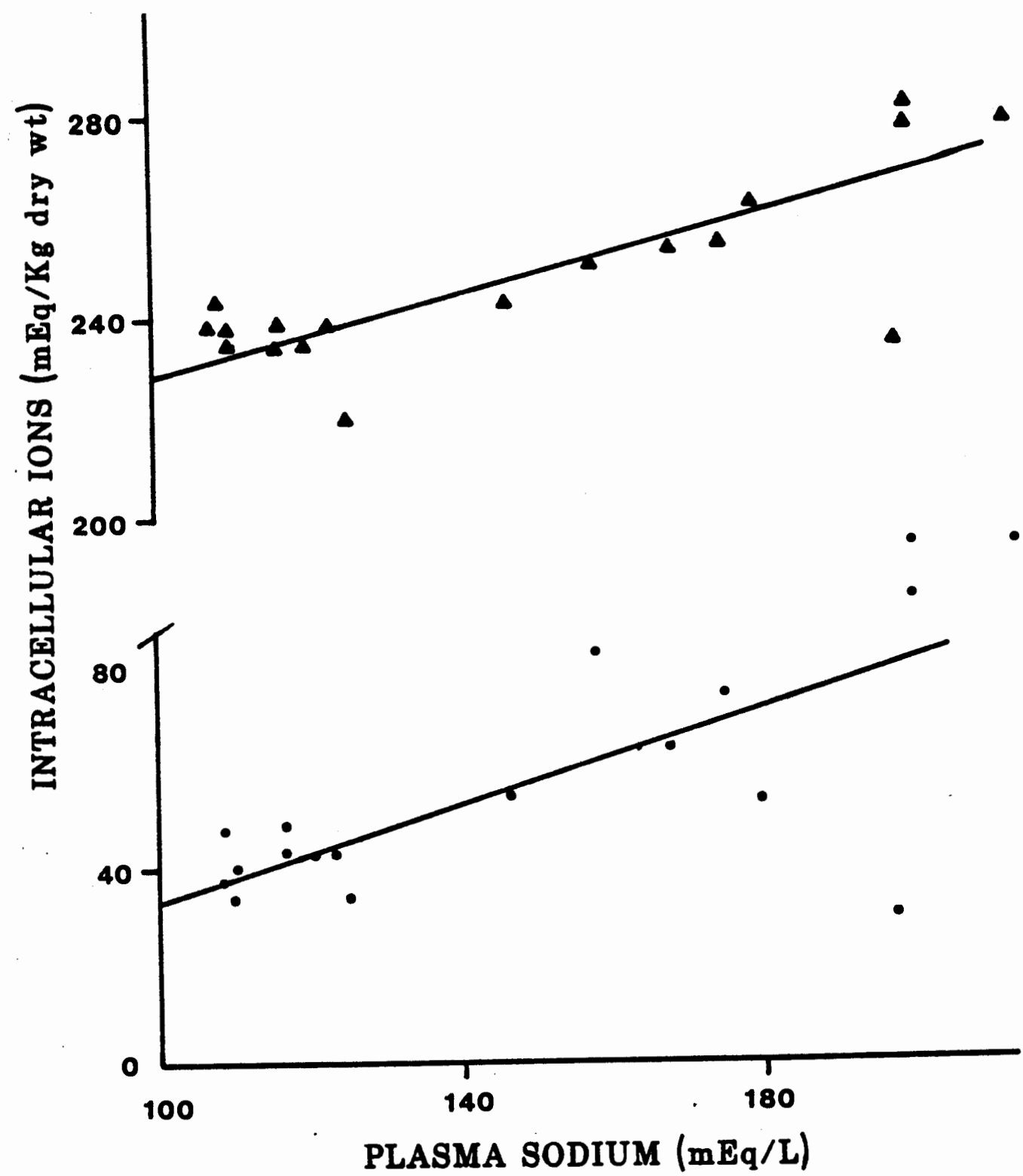

Figure 6. The relationship between red cell

intracellular ion concentrations and plasma electrolytes in B. marinus corrected for $10 \%$ trapped plasma.

( $)$ sodium $y=0.5 x-14, r=.73 ; \Delta$ potassium $y=0.4 x+190$, $r=.79)$. 
24

Figure 7. The relationship between Be marinus hematocrit and the In transformation of red cell viscosity at a shear rate of $450 / \mathrm{sec}$ and $20^{\circ} \mathrm{C}$. Solid I line is salt loaded $(180 \mathrm{mEq} / \mathrm{L})$, In $y=0.028$ $( \pm .001) x+0.90( \pm .04), r=.98$. Dashed I line is isotonic plasma. In $y=0.035( \pm .002) x+0.43( \pm .07)$, $r=.93$. 


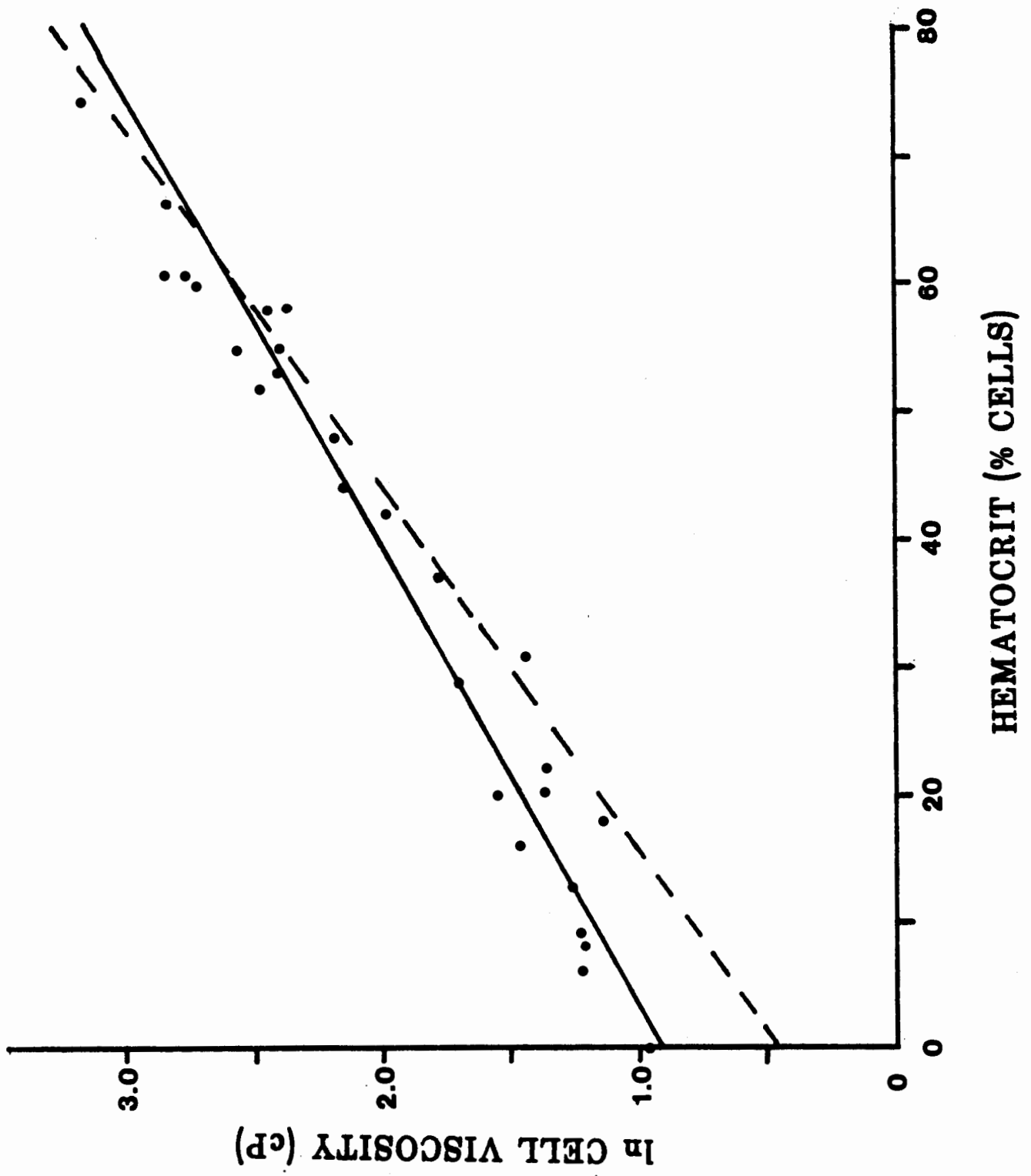




\section{DISCUSSION}

B. catesbelana and $B$. marlnus regulate red blood cell volume during dehydration, (FIgure 1). In vitro experiments in hypertonic media indicate similar responses for red blood cells of both species and a common mechanism for volume regulation. Figure 2 shows the biphasic nature of volume regulation in RBC's. Initially, cells in hypertonlc medla shrink, followed by volume recovery within $45 \mathrm{~m} i n$ for cells maintained at $200 \mathrm{C}$. The initial shrinkage is not significantly different from cell behavior as an osmometer. Kregenow (1971b), Cala (1977), and Amende and Plerce (1980), demonstrated a similar biphaslc volume regulation for red cells in ducks, flounder, and molluscs. Shown by Figure 2 is the temperature dependence of volume regulation, since cells maintained at $90 \mathrm{C}$ require a longer time to regain volume in hypertonic media than cells at 200C. Temperature dependence indicates a mechanism Involving an active uptake of plasma osmolytes. Additional experiments were designed to test volume regulation in the face of a $\mathrm{Na} / \mathrm{K}+$ pump blockade by oubain $(10-3 \mathrm{M})$, as well as cell osmotic behavior in potassium free Ringer's. R.

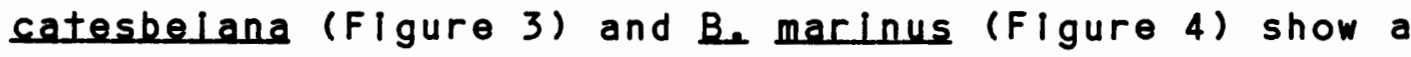
regulatory behavior in $\mathrm{Kt}$ free solution which is not 
significantly different from an osmometer $(p>0.05)$. Oubain falls to affect volume regulation since this treatment is not signiticantly different from cell behavior in normal media. These results are in agreement with data presented for red cells of ducks and polychaete worms by Kregenow (1971b) and Costa and Plerce (1983).

Figure 5 (Rana) and Figure 6 (Bufo) demonstrate sodium and potassium uptake during dehydration, indicating the importance of these cations in maintenance of RBC volume. Schmidt-Nielsen (1975) found sodium permeability increased for flounder red blood cells in hypertonic media. Kregenow (1971b) showed an Increase of intracellular potassium in duck red cells exposed to hyperosmotic shock. Volume regulation requires extracellular $k+$ avallablility. Potassium is accumulated against a concentration gradiant in both species. Schmidt and McManus (1974) describe a $\mathrm{Na}^{+}$ and $\mathrm{K}^{+}$uptake which is oubain insensitive and facilitates cation movement during volume regulation. Nakao et al. (1963) isolated from human red blood cells a $\mathrm{Na}^{+}, \mathrm{K}+$ ATPase which was not inhibited by oubain.

To summarize, volume regulation of RBC's in the two anurans studied is achleved by active uptake of plasma potassium via an oubain insensitive pump and movement of plasma sodium down a concentration gradient. These results are in agreement with previous studies. In addition, this study demonstrates volume regulation and ionic uptake 
during dehydration. Previous studies have largely involved mammalian or avian cells which do not normally experience markedly increased plasma electrolytes with dehydration.

Volume regulation achleved by uptake of ions offers an opportunity to offset general circulatory insufficiency accompaning dehydration. The effect of lonic mediators of hemoglobin function is to reduce Hb oxygen affinity. The effect of salts in lowering oxygen affinity is thought to reflect preferential binding of salts by deoxygenated as opposed to the oxygenated form of hemoglobin (Tyuma 1974). A shift of the oxygen dissociation curve to the right has been implicated in the adaptation to anemla and hypoxic hypoxla in sheep (Lenfant et al. 1970). In this manner, increased intracellular electrolytes could substantially increase delivery of oxygen to the tissues and be adaptive in terrestrial species to extend tolerance to dehydration. Control $P_{50}$ determinations for both species are in agreement with published values established under similar conditions (Hall, 1968; Tazawa et al., 1979).

Dehydrated individuals do not have a significantly different oxygen affinity. Increased intracellular concentrations do not prove to be adaptive for delivery of oxygen during dehydration in elther species. This seemingly anomalous finding may be explained in terms of increased oxygen affinity caused by other modiflers of $\mathrm{Hb}$ 
function such as organic phosphates which override the effects of salts.

Blood flow rate is inversely proportional to blood viscosity. Blood viscosity is a combined term which includes the viscosity of the two componants of whole blood, blood plasma and red blood cells. The non-Newtonian behavior of whole blood is assoclated with substantial proteln concentrations and suspended red cells. B. marinus plasma viscosity increased with increased plasma sodium. Ionic interactions with plasma protein were presumably responsible for the significantly higher intercept for salt loaded blood (FIgure 7).

Red blood cell viscosity is dependent on shape, volume, membrane rigidity, and mean corpuscular hemoglobin. concentration (MCHC). Erslev and Atwater (1963) found nearly a doubling of viscosity as MCHC Increased from 24\%-38\%. In B. marinus, the slope of the line in Figure 7 for salt loaded cells, (non-regulating), is significantly lower than the slope of the line for cells in normal plasma. These slopes represent cell viscosity since the second component of the slope, plasma viscosity, remains constant. I therefore argue that nonregulating red blood cells in hypertonic plasma are more distensible and therefore less viscous than normal cells in isotonic Plasma, (dashed Iine, Figure 7). Rand and Burton (1964) found human red cell membranes in hypertonic solution (1.2\% 
$\mathrm{NaCl}$ ), to be more distensible than membranes in isotonic or hypotonic media. Melselman et al. (1967) found human red cells in hypertonic plasma to be more viscous than cells in hypotonic plasma. Their reported values lack estimates of variability and may merely reflect increased plasma viscosity.

Within a physlologic range of hematocrits, blood viscosity in Be marlnus is lower for red blood cells which regulate volume. This may not represent a true viscosity advantage for regulating cells, since if correction is made for plasma viscosity, the previous advantage disappears. Constraints for regulation of cellular volume in red blood cells may therefore include factors other than viscosity. One such selective pressure for maintenance of cell volume might be the proper function of membrane bound enzyme systems.

In summary, R. catesbeiana and $B_{\text {. }}$ marinus maintain red blood cell volume during dehydrational stress by uptake of sodium and potassium. Increased intracellular ionic concentrations do not alter oxygen delivery by shifting the oxygen dissoclation curve to the right. Hypertonic plasma does not appear to increase red cell viscosity although whole blood viscosity is higher for hematocrits less than 70\%. Increased viscosity in salt loaded blood may be largely attributed to increased plasma viscosity. 
Volume regulation of red cells occurs but is insufficient to cancel the effect of increasing plasma viscosity. 


\section{REFERENCES}

Adams, R.B., and Gregg, E.C. (1972) Pulse shapes from particles traversing Coulter oriface fields.

Phys. Med. Biol. 17(6):830-842

Amande, L.M., Pierce, S.K. (1980) Cellular volume regulation in salinity stressed molluscs: The response of Neetla penderesa (Arcidae) red blood cells to osmotic variation. J. Comp. Physiol. $138: 283-289$

Atkins, J.M., Wildenthal K. and Horowitz, L.D. (1973) Cardiovascular responses to hyperosmotic mannitol in anesthetized and concious dogs. Am. J. Physiol. $225: 132-137$

Bentley, P.J. (1966a) Adaptations of amphibla to arid environments. Science 152:619-623

Bentley, P.J. (1966b) The physlology of the urinary bladder of amphibia. Biol. Rev. 41:275-316

Braasch, D. (1971) Red cell deformability and capillary blood flow. Physiol. Rev. 51(4):679-700

Brunori, M., Falcioni, G., Fortuna, G., and Giardina, B. (1975) Effect of anions on the oxygen binding properties of the hemoglobin componants from trout ( $\mathrm{Salmo}$ irldeus). Arch. Biochem. Biophys. $168: 512-519$

Cala, P.M. (1977) Volume regulation by flounder red blood cells in anisotonic media. J. Gen. Physiol. $69: 537-552$

Costa, C.J., and Pierce, S.K. (1983) Volume regulation in the red coelomocytes of Glycera dibranchiata:

An interaction of amino acid and $K^{+}$effluxes. J. Comp. Physiol. 151:133-144

Edwards, M.J. and Martin, R.J. (1966) Mixing tecnique for the oxygen-hemoglobin equilibrium and Bohr effect. J.Appl. Physiol. 21(6):1898-1902

Erslev, A.J., and Atwater, J. (1963) Effect of mean corpuscular hemoglobin concentration on viscosity. J. Lab. Clin. Med. 62:401-406 
Fugelli, K. (1967) Effect of cell volume in flounder erythrocytes accompanied by a decrease in plasma osmolarity. Comp. Biochem. Physiol.22:253-260

Hall, F.G. (1966) Hemoglobin functions in the blood of Bufe marinus. J Cell Physiol. 68:69-73

HIIIman, S.S. (1976) Cardiovascular correlates of maximal oxygen consumption rates in anuran amphibians. J. Comp. Physiol. 109:199-207

HIIIman, S.S. (1978) The roles of oxygen delivery and electrolyte levels in the dehydrational death of Xenopus Laevis. J. Comp. Physiol. 128:169-175

Hillman, S.S. (1980) Physlological correlates of differential dehydration tolerance in anurans. Copeia $1: 125-129$

Hillman, S.S., and Sommerfeldt, R.W. (1981) Microsphere studies of amphibian systemic blood flow redistribution during dehydration, hypovolemia, and salt load. J. Exp. Zool. 218:305-308

HIIIman, S.S. (1984) Inotroplc influence of dehydration and hyperosmolal solutions on amphiblan cardiac muscle. J. Comp. Phys. 154:325-328

Katz, U. (1978) Ionic and volume regulation in selected tissues of the euryhalline toad Bufo virldis.

Al fred Benzon Symposium XI, Munksgaard

Kock-Weser, J. (1963) Influence of osmolarity of perfusate on contractility of mammalian myocardium. Am. J. Physiol. 204:957-962

Kregenow, F.M. (1971a) The response of duck erythrocytes to nonhemolytic hypotonic media. Evidence for a volume-controlling mechanism. J. Gen Physiol. $58: 372-395$

Kregenow, F.M. (1971b) The response of duck erythrocytes to hypertonic media. J. Gen. Physiol. 58:396-412

Lenfant, C., Torrance, J.D., Woodson, R., and FInch, C.A. (1970) Adaptation to hypoxia. In Red Cell

Metabelism and Eunction. ed. G.J. Brewer, Plenum Press, New York pg. 203-212 
McClanahan, L. (1967) Adaptations of the spadefoot toad Scaphlopus ceuchll, to desert environments.

Comp. Blochem. Physiol. 20:73-99

Meiselman, H.J., Merrill, E.W., Gilliland, E.R.,

Pelletier, G.A., and Salzman, E.W. (1967)

Influence of plasma osmolarity on the rheology of

human blood. J. Appl. Physiol. 22(4):772-781

Metcalf, J. and Dhindsa, D.S. (1970) A comparison of the mechanisms of oxygen transport among several mammalian species. In Red Cell Metabelism and Eunction. ed. G.J. Brewer, Plenum Press, New York Pg. 229-240

Nakao, T., Nagano, K., Adachl, K., Nakao, M. (1963) Separation of two adenosine triphophatases from erythrocyte membrane. Blochem. Blophys. Res. Comm. $13: 444-448$

Rand, R.P., and Burton, A.C. (1964) Mechanical properties of the red cell membrane. Blophys. J. 4:115-135

Rossi-Fanelli, A., Antonini, E., and Caputo, A. (1961) Studies on the relations between molecular and functional properties of hemoglobin.

J. Biol. Chem. 236(2):397-400

Rulbal, R. (1962) The adaptive value of bladder water in the toad, Bute ceanatus. Physiol. Zool. 35:218-223

Schmidt,W.F., and Mcmanus, T.J. (1974) Furosemidesensitive co-transport of $\mathrm{Na}^{+} \mathrm{plus} \mathrm{K}^{+}$into duck red cells activated by hypertonicity or catecholamines. Fed.Proc. 33(5):1457

Schmidt-Nielsen, B. (1975) Comparative physlology of cellular ion and volume regulation. J. Exp. Zool. $194: 207-220$

Shoemaker, V.H. (1964) The effects of dehydration on electrolyte concentrations in a toad Bufo marinus. Comp. Biochem. Physiol. 13:261-271

Tazawa, H., Mochizukl, M., and Pilper, J. (1979)

Blood oxygen dissociation curve of the frogs

Rana catesbelana and Rana brevipoda. J. Comp. Physiol. 129:111-114

Thorson, T.B. (1955) The relationship of water economy to terrestrialism in amphibians. Ecology 36:100-116 
Tyuma, 1. (1974) Gas transport.

In Cellular and Molecular Blology of Erythrocytes.

ed. H. Yoshlkawa and S.M. Rapoport

University Park Press, Baltimore pg.279-305

Wildenthal, K., Adcock, R.C., Crie, J.S.,

Templeton, G. H (1975) Negative inotroplc influence of hyper-osmotic solution on cardiac muscle.

Am. J. Physlol. 1505-1509 